http://dx.doi.org/10.5800/GT-2015-6-2-0181

\title{
XXVI ALL-RUSSIA YOUTH CONFERENCE “LITHOSPHERE STRUCTURE AND GEODYNAMICS”, IRKUTSK, RUSSIA, APRIL 20-25, 2015
}

\author{
E. V. Sklyarov, A. A. Dobrynina, A. M. Kononov \\ Institute of the Earth's Crust, Siberian Branch of RAS, Irkutsk, Russia
}

Abstract: The report presents a chronicle of the XXVI All-Russia youth conference "Lithosphere structure and Geodynamics", dedicated to the 85th anniversary of academician Nikolai A. Logachev - outstanding geologist, specialist on the continental rifting. The major events are highlighted and a thematic review of the conference papers is given.

Key words: lithosphere, geodynamics, tectonics, magmatism, metamorphism, geochemistry, hydrogeology, engineering geology, Geographic Information Systems, geophysics, mineralogy, geomorphology.

Recommended by D.P. Gladkochub

For citation: Sklyarov E.V., Dobrynina A.A., Kononov A.M. 2015. XXVI All-Russia youth conference "Lithosphere structure and Geodynamics", Irkutsk, Russia, April 20-25, 2015. Geodynamics \& Tectonophysics 6 (2), 267-274. doi:10.5800/GT-2015-6-2-0181.

\section{XXVI ВСЕРОССИЙСКАЯ МОЛОДЕЖНАЯ КОНФЕРЕНЦИЯ «СТРОЕНИЕ ЛИТОСФЕРЫ И ГЕОДИНАМИКА», ИРКУТСК, РОССИЯ, 20-25 АПРЕЛЯ 2015 Г.}

\section{Е. В. Скляров, А. А. Добрынина, А. М. Кононов}

Институт земной коры СО РАН, Иркутск, Россия

Аннотация: В сообщении представлена хроника проведения XXVI Всероссийской молодежной конференции «Строение литосферы и геодинамика», посвященной 85-летию со дня рождения академика Николая Алексеевича Логачева - выдающегося геолога, специалиста по континентальному рифтогенезу. Освещены основные события и дан тематический обзор докладов конференции.

Ключевые слова: литосфера, геодинамика, тектоника, магматизм, метаморфизм, геохимия, гидрогеология, инженерная геология, геоинформационные системы, геофизика, минералогия, геоморфология. 
С 20 по 25 апреля 2015 года в Институте земной коры Сибирского отделения РАН (ИЗК СО РАН, г. Иркутск) состоялась традиционная XXVI Всероссийская молодежная конференция «Строение литосферы и геодинамика», посвященная 85-летию со дня рождения академика Николая Алексеевича Логачева, крупного специалиста в области вулканизма, неотектоники, геоморфологии, стратиграфии и литологии кайнозойских и мезозойских отложений Восточной Сибири, Монголии и Восточной Африки. Конференция была организована силами Совета молодых ученых ИЗК при финансовой поддержке РФФИ (проект № 15-35-10075_мол-г) и дирекции ИЗК СО РАН.

Всероссийская молодежная конференция «Строение литосферы и геодинамика» проводится в ИЗК СО РАН с 1959 года (с некоторым перерывом), первоначально заседания конференции проводились ежегодно, в настоящее время проходят раз в два года.

В состав Оргкомитета XXVI Всероссийской молодежной конференции под председательством членакорреспондента РАН Е.В. Склярова вошли ведущие ученые Института земной коры СО РАН, Института геохимии СО РАН (ИГХ СО РАН, Иркутск), Иркутского государственного университета (ИГУ) и Национального исследовательского Иркутского государственного технического университета (НИ ИрГТУ).
По данным Оргкомитета, в конференции приняли очное и заочное участие 197 ученых из 33 городов России, Белоруссии, Украины, Казахстана, Китая, Вьетнама и Франции, представляющие $\mathbf{5 1}$ организацию (из которых 25 - научно-исследовательские институты, 18 - высшие учебные заведения и 8 - нефтяные, геофизические и геологоразведочные компании) (рис. 1).

К началу работы конференции издан сборник материалов объемом 245 страниц, включающий тезисы 114 докладов молодых ученых и 7 пленарных докладов (Строение литосферы и геодинамика: Материалы XXVI Всероссийской молодежной конференции (г. Иркутск, 20-25 апреля 2015 г.). Иркутск: Институт земной коры СО РАН, 2015. 245 c.). Сборник можно загрузить c web-сайта Института земной коры CO PAH (http://www.crust.irk.ru/ images/upload/newsfond155/594.pdf).

Хронология конференции. Работа XXVI Всероссийской молодежной конференции «Строение литосферы и геодинамика» началась 20 апреля с геологической экскурсии на карьер по добыче мрамора «Перевал», г. Слюдянка, под руководством чл.-корр. РАН Е.В. Склярова. В рамках экскурсии участники конференции посетили мраморный карьер и проявления апатитовых руд.

21 апреля в конференц-зале ИЗК СО РАН состоялось торжественное открытие конференции, участ-

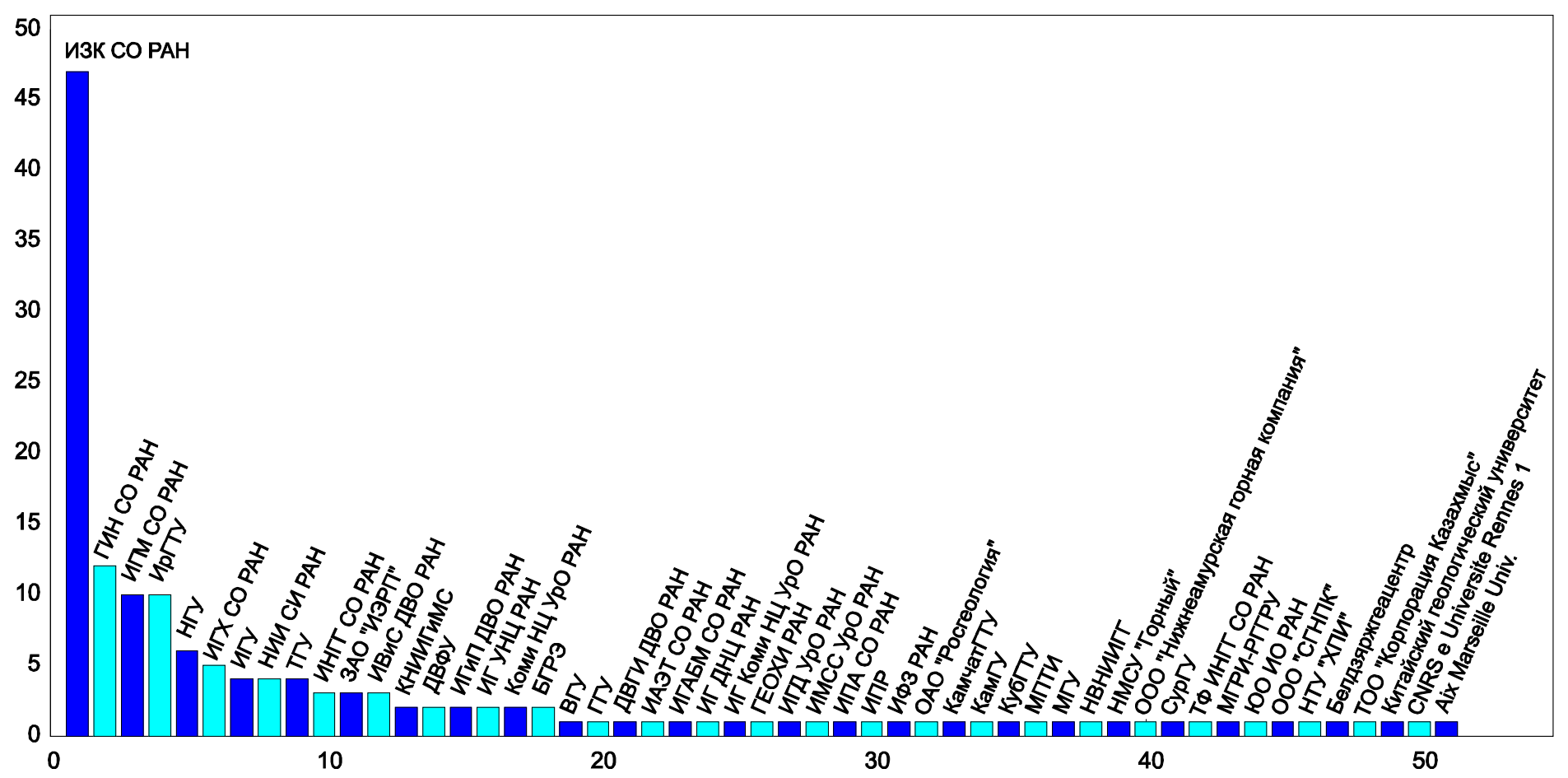

Рис. 1. Распределение количества присланных докладов по организациям.

Fig. 1. Reports and organizations chart. 


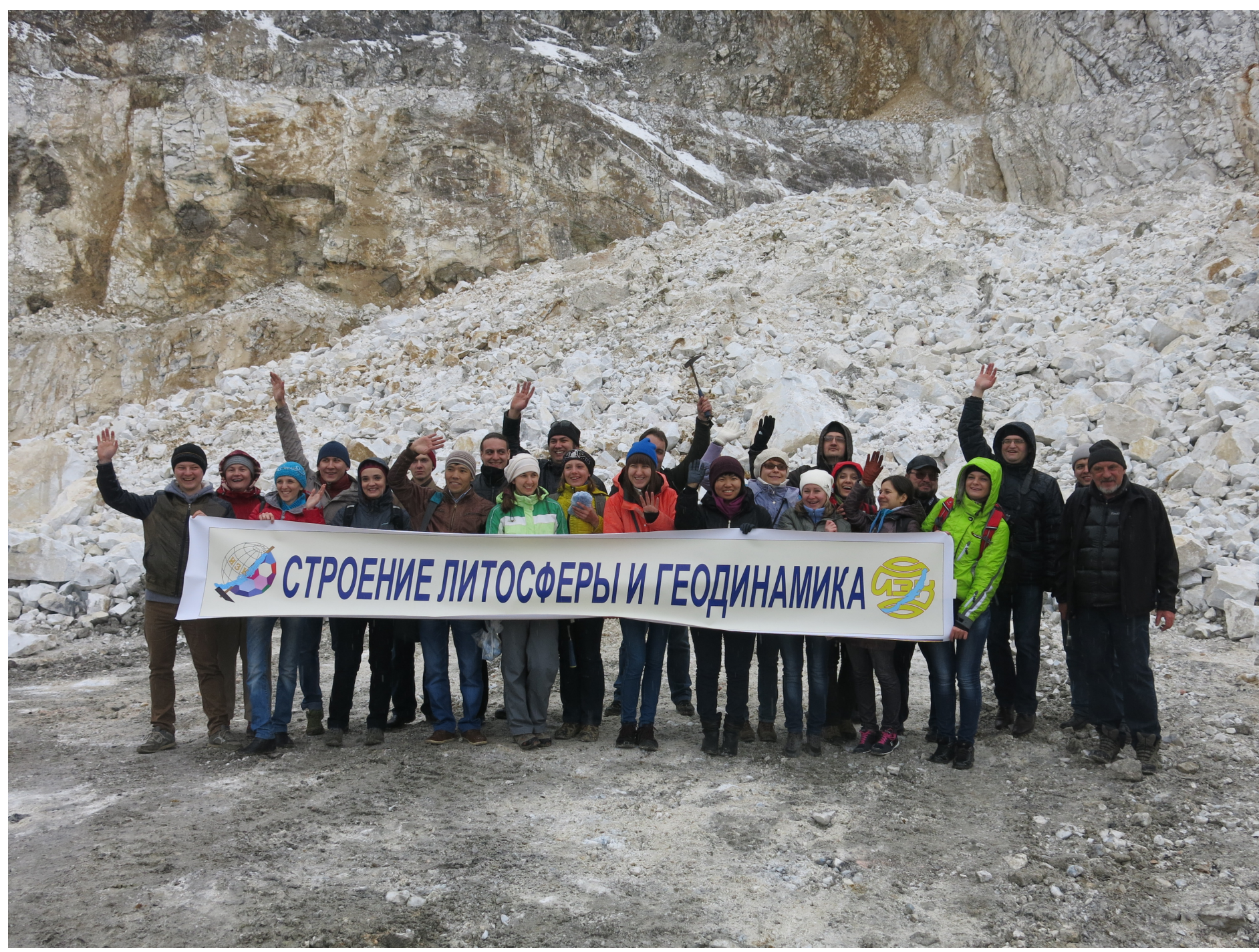

Рис. 2. Участники конференции во время геологической экскурсии на карьер «Перевал».

Fig. 2. The group of the conference participants who took to the geological excursion to the Pereval Quarry near Slyudyanka, Irkutsk region.

ников совещания приветствовали председатель Оргкомитета Е.В. Скляров и директор ИЗК СО РАН д.г.-м.н. Д.П. Гладкочуб. С 21 по 23 апреля проводились рабочие заседания пяти научных секций, организованных в соответствии с тематикой заявленных докладов. Каждая секция открывалась пленарными докладами ведущих научных сотрудников ИЗК СО РАН. По завершении программы заседаний каждой секции проходило обсуждение представленных докладов и дискуссия по вопросам, связанным с их тематикой. Тематика секций:

Секция 1. Общая геология, тектоника, осадочная геология и палеонтология (21 апреля, утреннее заседание, конвинеры: чл.-корр. РАН, д.г.-м.н. Е.В. Скляров, ИЗК СО РАН, д.г.-м.н. А.М. Мазукабзов, ИЗК СО РАН, З.Л. Мотова, ИЗК СО РАН).

Секция 2. Геохимия, петрология, минералогия и рудообразование (21 апреля, вечернее заседание, конвинеры: д.г.-м.н. В.А. Макрыгина, ИГХ СО РАН, д.г.-м.н. А.В. Иванов, ИЗК СО РАН, А.В. Левин, ИЗК СО PAH).

Секция 3. Тектонофизика, современная геодинамика, неотектоника и геоморфология (22 апреля, утреннее заседание, конвинеры: д.г.-м.н. С.И. Шерман, ИЗК СО РАН, д.г.-м.н. К.Ж. Семинский, ИЗК СО РАН, А.А. Гладков, ИЗК СО РАН).

Секция 4. Геофизика, геофизические методы исследований и геоинформатика (22 апреля, вечернее заседание, конвинеры: д.г.-м.н. В.С. Имаев, ИЗК CO РАН, д.г.-м.н. В.И. Мельникова, ИЗК СО РАН, к.ф.М.н. А.А. Добрынина, ИЗК СО РАН).

Секция 5. Гидрогеология, инженерная геология и нафтидогенез (23 апреля, утреннее заседание, конвинеры: д.г.-м.н. Т.Г. Рященко, ИЗК СО РАН, 


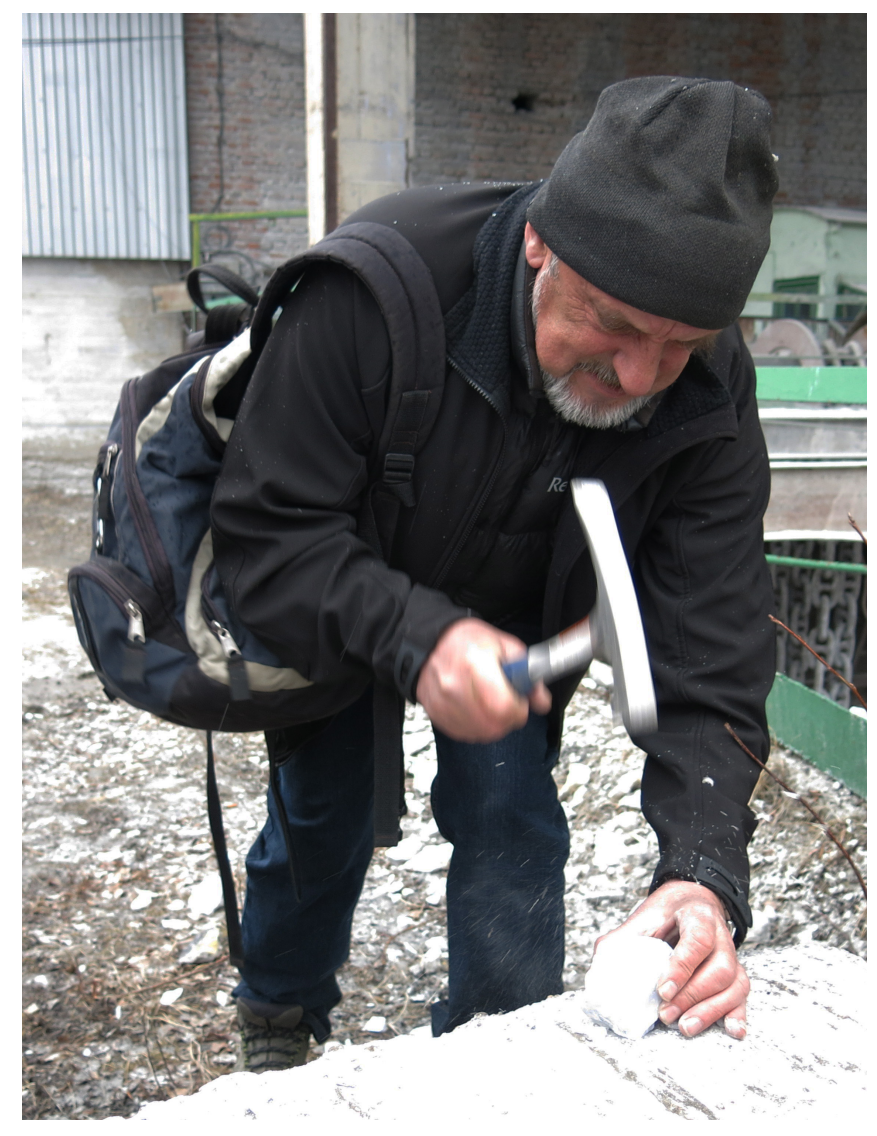

Рис. 3. Рабочие моменты: геологическая экскурсия на карьер «Перевал», г. Слюдянка (член-корреспондент РАН Е.В. Скляров).

Fig. 3. During the geological excursion to the Pereval Quarry near Slyudyanka, Irkutsk region (E.V. Sklyarov, Corresponding Member of RAS).

к.г.-м.н. Е.А. Козырева, ИЗК СО РАН, В.А. Пеллинен; вечернее заседание, конвинеры: д.г.-м.н. В.А. Скворцов, ИЗК СО РАН, д.Г.-м.н. А.Г. Вахромеев, ИЗК СО РАН, к.г.-М.н. А.М. Кононов, ИЗК СО РАН).

Вечером 23 апреля состоялась стендовая секция, включавшая 27 докладов. В завершение конференции был заслушан доклад члена-корреспондента РАН Е.В. Склярова «Практические советы по подготовке публикаций и презентаций докладов», за которым последовали общая дискуссия и закрытие конференции. 24-25 апреля участники конференции выезжали в Тункинскую впадину, где были проведены следующие экскурсии:

- гидрогеологическая экскурсия «Аршан-Тункинское месторождение углекислых минеральнолечебных вод» (к.г.-м.н. Ю.И. Кустов),

- инженерно-геологическая экскурсия «Селевые потоки в окрестностях поселка Аршан 28 июня 2014 года: причины и последствия» (к.г.-м.н. А.В. Кадетова).

Тематический обзор конференции. Секция конференции «Общая геология, тектоника, осадочная геология и палеонтология» открылась пленарным докладом директора ИЗК СО РАН, д.г.-м.н. Д.П. Гладкочуба о роли Сибирского кратона в структуре суперконтинентов докембрия. После пленарного доклада последовали выступления молодых ученых, в которых рассматривались вопросы развития отдельных тектонических структур, часть докладов была посвящена исследованию вулканогенных и вулканогенно-осадочных пород, стратиграфии и вопросам возраста терригенных отложений. Были представлены результаты применения магнитной градиентометрии при поисках золоторудных месторождений, рассматривались вопросы рациональной разработки месторождений нефти.

Секцию конференции «Геохимия, петрология, минералогия и рудообразование» открыл пленарный доклад д.г.-м.н. А.В. Иванова «Датирование цирконов U-Pb методом: TIMS, SIMS, LA-ICPMS и другие (не)понятные вещи». На секции обсуждались вопросы датирования пород различными методами, рассматривались геохимические особенности бурых суглинков и погребенных почв Приморского края и особенности состава минералов Катугинского редкометалльного и Шерловогорского олово-полиметаллического месторождений. Прозвучали доклады о результатах исследования влияния флюидного режима на мобилизацию элементов в гранитной системе и термодинамического моделирования взаимодействия толеит-базальтовой магмы с карбонатно-эвапоритовыми отложениями чехла Сибирской платформы. Были представлены исследования минералого-петрографических особенностей UHP гранатитов Кокчетавского

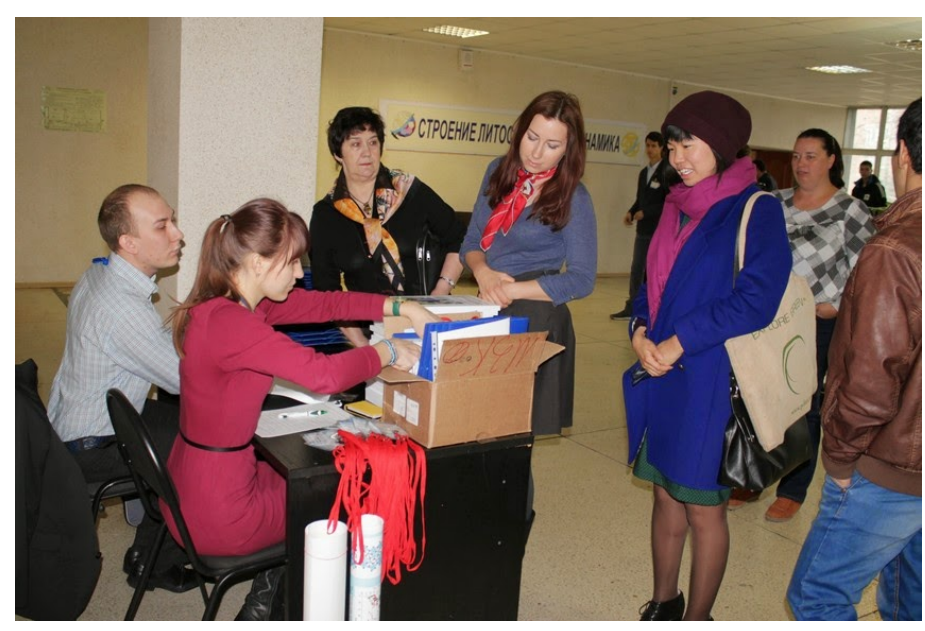

Рис. 4. Регистрация участников конференции.

Fig. 4. Registration of the conference participants. 


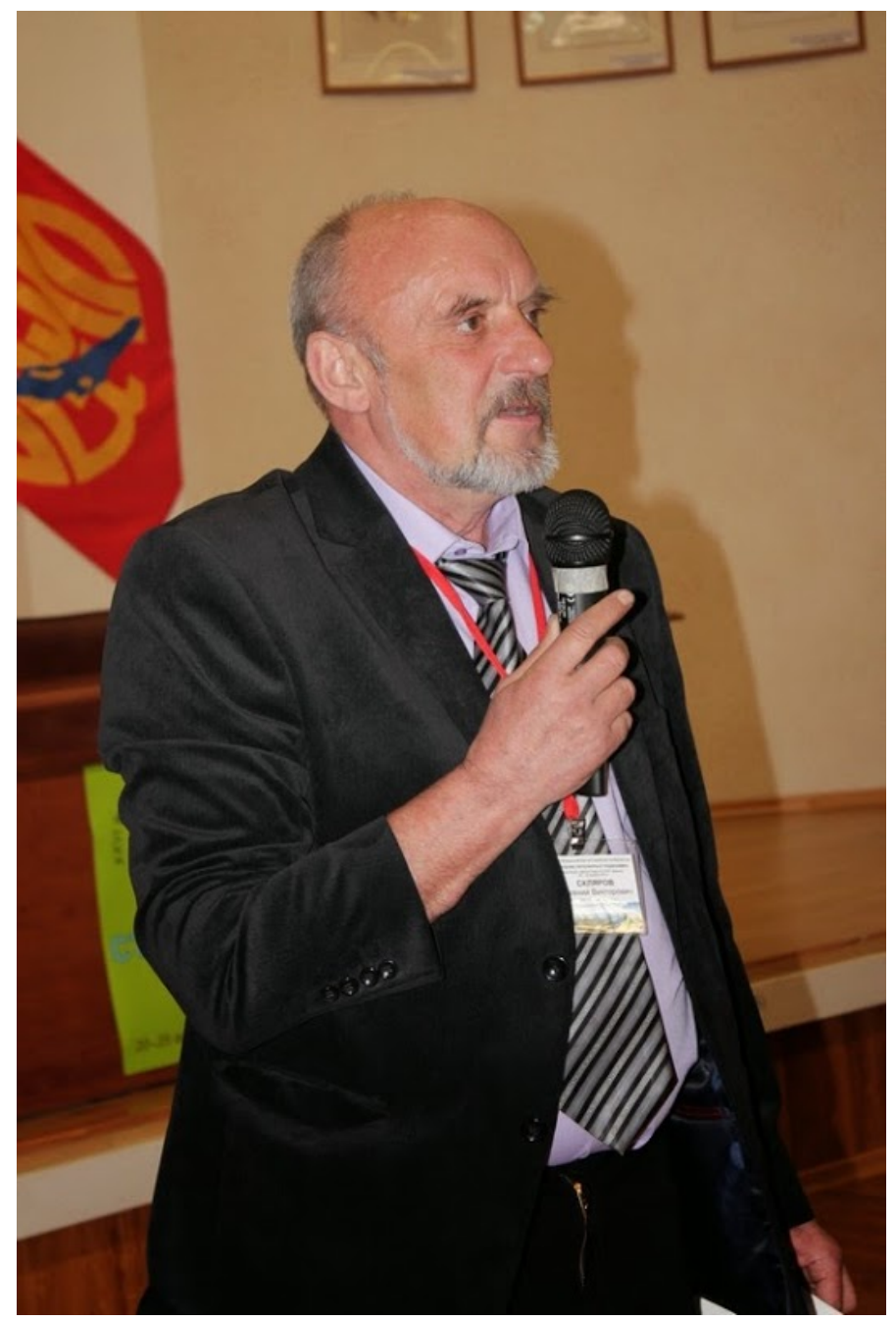

Рис. 5. Открытие конференции: приветственное слово председателя Оргкомитета - члена-корреспондента РАН Е.В. Склярова.

Fig. 5. The conference opening meeting. Welcome speech by E.V. Sklyarov, Corresponding Member of RAS, Organizing Committee Chairman.

массива (Казахстан) и щелочных гранитоидов Шербахтинского массива (Западное Забайкалье). Часть докладов имела экологическую направленность и касалась вопросов исследования загрязнения ртутью снежного покрова и определения корреляционных взаимоотношений элементов в потоке рассеяния хвостохранилища, а также оценки влияния верховых пожаров на изменение геохимического фона в почвенно-растительном покрове и влияния форм нахождения химических элементов в почвах на их бионакопление.

В рамках секции «Тектонофизика, современная геодинамика, неотектоника и геоморфология» прозвучало три пленарных доклада: «О природе первичной разномасштабной делимости формирующейся и современной литосферы Земли» (д.г.-м.н.

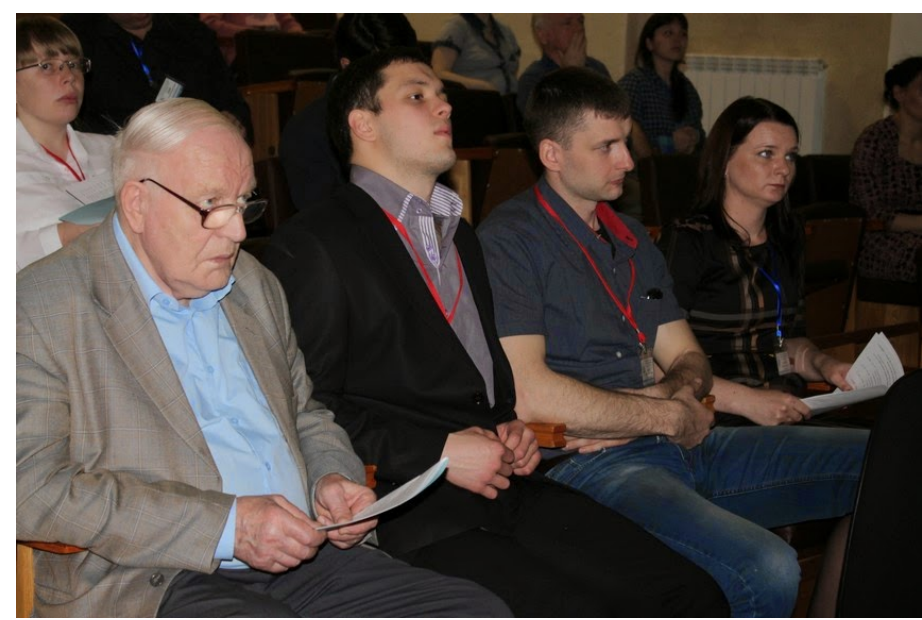

Рис. 6. На заседании.

Fig. 6. Meeting during the conference.

С.И. Шерман), «Палеосейсмогеология Сибири: методы, опыт практического применения, перспективы и реальность» (д.г.-м.н. В.С. Имаев) и «Позднеплейстоценовое оледенение Восточного Саяна» (к.г.-м.н. С.Г. Аржанников). В докладах молодых ученых был представлен широкий спектр проблем современной геодинамики и тектонофизики - от вопросов физического и оптического моделирования и построения расчетных моделей локализации опасных геологических процессов при сильных землетрясениях до реконструкции полей тектонических напряжений структурными методами, дешифрирования космических снимков и возможностей сейсмодеформационного мониторинга. Были озвучены результаты разработки базы данных

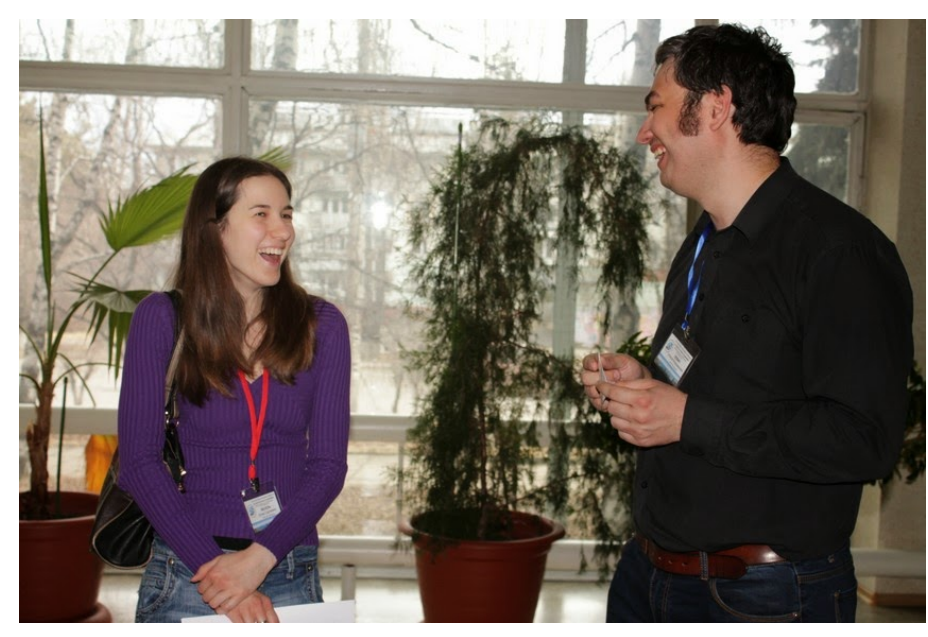

Рис. 7. Общение коллег в неформальной обстановке.

Fig. 7. Informal communication of colleagues. 

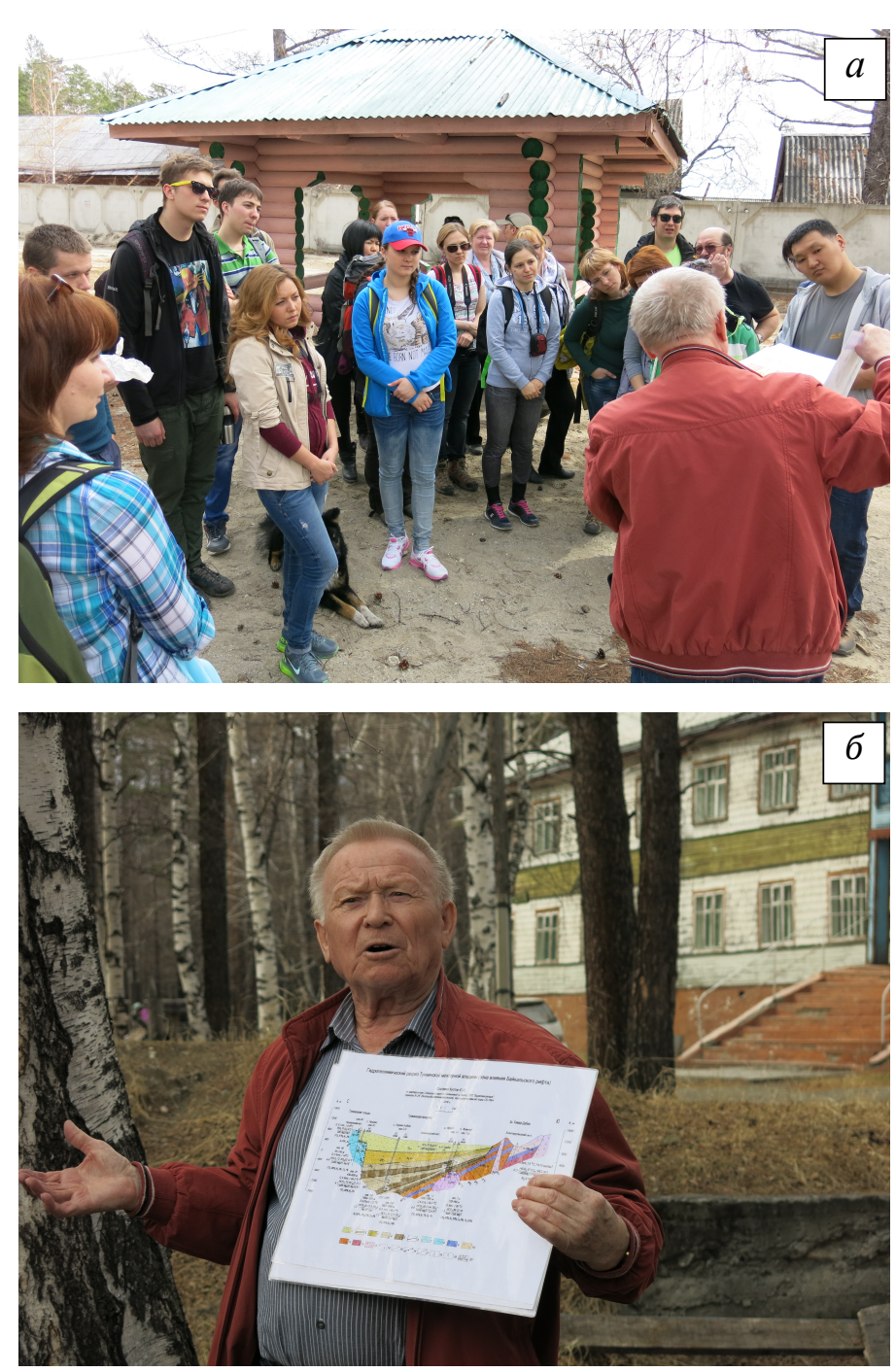

Рис. 8, $\boldsymbol{a}$, б. Рабочие моменты конференции: гидрогеологическая экскурсия «Аршан-Тункинское месторождение углекислых минеральнолечебных вод» (к.г.-м.н. Ю.И. Кустов).

Fig. 8, $\boldsymbol{a}, \boldsymbol{\sigma}$. The hydrogeological excursion to the ArshanTunka carbonate mineral water deposit (Yu.I. Kustov, $\mathrm{PhD})$.

сейсмогенных источников юга Восточной Сибири и пакета ГИС-программ для оценки пространственно-временных закономерностей проявления сейсмичности.

Секция «Геофизика, геофизические методы исследований и геоинформатика» открылась пленарным докладом д.г.-м.н. В.И. Мельниковой, посвященным проблемам очаговой сейсмологии. Доклады молодых ученых касались вопросов малоглубинной геофизики, сейсмического районирования, а также «очистки» каталога региональных землетрясений Прибайкалья от роев и афтершоков. В ряде сообщений прозвучали результаты ис- следований затухания сейсмических волн и глубинного строения Байкальского рифта и Центральной Азии.

Секция «Гидрогеология, инженерная геология и нафтидогенез» была разделена на два заседания. Утреннее заседание, посвященное вопросам гидрогеологии и инженерной геологии, открылось пленарным докладом к.г.-м.н. Е.А. Козыревой «Трансформация геологической среды Сибирского региона (инженерно-геологический аспект)». Сообщения молодых ученых были посвящены моделированию физико-химических процессов в термальных источниках, оценке роли геолого-структурных условий в формировании месторождений подземных вод, исследованию соленых озер Забайкалья, а также вариациям концентраций радона в подземных водах и их связи с подготовкой и реализацией

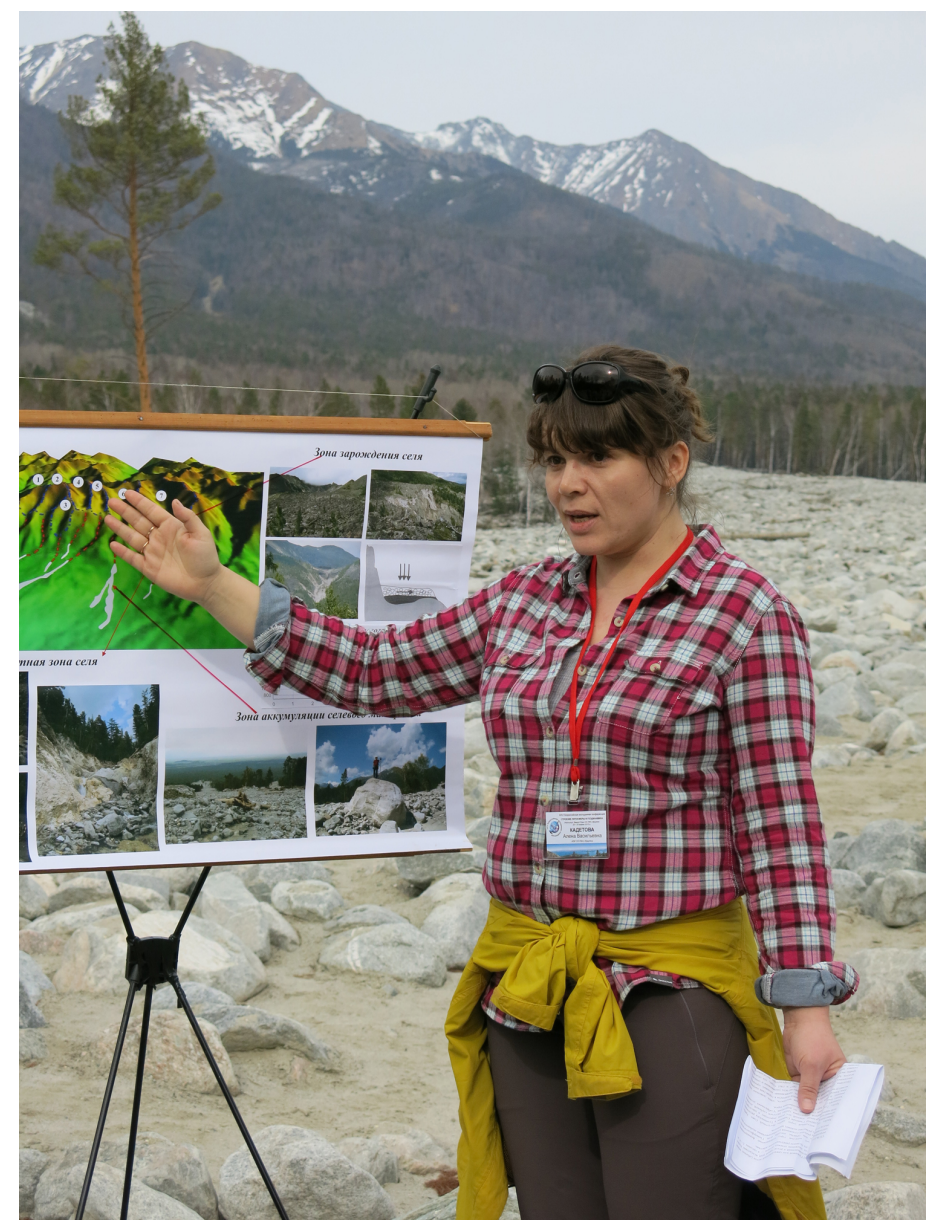

Рис. 9. Рабочие моменты конференции: инженерногеологическая экскурсия «Селевые потоки в окрестностях поселка Аршан 28 июня 2014 года: причины и последствия» (к.г.-м.н. А.В. Кадетова).

Fig. 9. The engineering geological excursion. Subject: Mudflows of 28 June 2014 in the vicinity of the Arshan settlement. Causes and consequences (A.V. Kadetova, PhD). 
землетрясений. Кроме того, часть докладов касалась мониторинга термодинамического состояния грунтов, исследования физико-механических свойств протерозойских песчаников и химического состава снежного покрова и его связи с лесными пожарами.

Вечернее заседание секции, посвященное вопросам гидрогеологии и нафтидогенеза, началось с пленарного доклада д.г.-м.н. А.Г. Вахромеева о геологическом строении природного резервуара карбонатного рифея на Юрубчено-Тохомском НГКМ. В секционных сообщениях обсуждались вопросы уточнения геологического строения нефтяных месторождений, оценки фильтрационно-емкостных свойств нефтяных пластов, а также методы увеличения нефтеотдачи на месторождениях. Часть докладов касалась проблем гидрогеологии, в них рассматривалась систематизация источников подземных вод по содержанию радона, особенности взаимодействия техногенных вод и рассолов на месторождениях нефти и газа, а также приводились результаты анализа распределения изотопов хлора в соленых водах и рассолах Западной Якутии.

Всего по данным Оргкомитета в рамках конференции молодыми учеными было представлено 55 устных и 27 стендовых докладов.

На общей заключительной дискуссии XXVI Bceроссийской молодежной конференции «Строение литосферы и геодинамика» прозвучали выступления председателя Оргкомитета, члена-корреспондента РАН Е.В. Склярова (ИЗК СО РАН), директора
ИЗК СО РАН д.Г.-м.н. Д.П. Гладкочуба, зам. директора ИЗК СО РАН д.г.-М.н. К.Г. Леви, К.г.-М.н. Е.А. Козыревой (ИЗК СО РАН), к.г.-М.н. А.М. Кононова (ИЗК СО РАН), С.В. Межеловской (МГРИ-РГГРУ, г. Москва), Ю.С. Восель (ИГМ СО РАН, г. Новосибирск), д.г.-м.н. А.В. Иванова (ИЗК СО РАН) и д.Г.-м.н. А.Г. Вахромеева (ИЗК СО РАН). В выступлениях старших коллег отмечался высокий научный уровень докладов молодых ученых, их хорошая подготовленность и знание вопроса. Подчеркивалась полезность конференции «Строение литосферы и геодинамика» для молодых ученых в плане представления полученных результатов, обмена мнениями и завязывания научных контактов, а также тренинга. Общей рекомендацией заседания было продолжать в дальнейшем собрания традиционной Всероссийской молодежной конференции «Строение литосферы и геодинамика».

В заключение Оргкомитет XXVI Всероссийской молодежной конференции «Строение литосферы и геодинамика» выражает благодарность всем ее участникам за активную работу, дирекции ИЗК СО РАН и Российскому фонду фундаментальных исследований - за оказанную финансовую поддержку (проект № 15-35-10075_мол-г), а также М.М. Кайсарову, зав. отделом по делам ГО и ЧС Слюдянского района, за помощь в организации геологической экскурсии на карьер «Перевал» и В.И. Сонголову, руководителю курорта «Аршан», за помощь в организации экскурсии в Тункинскую долину.
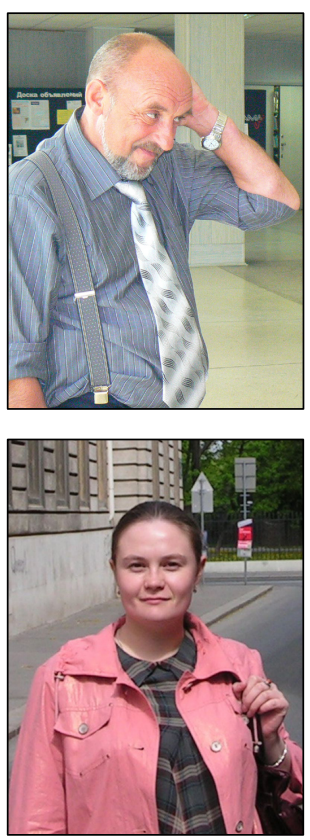

Скляров Евгений Викторович, член-корреспондент РАН, докт. геол.-мин. наук, профессор, г.н.с. Институт земной коры СО РАН

664033, Иркутск, ул. Лермонтова, 128, Россия

Тел.: 8(3952)511665; 《 e-mail: skl@crust.irk.ru

Sklyarov, Eugene V., Corresponding Member of RAS, Doctor of Geology and Mineralogy, Professor, Chief Researcher

Institute of the Earth's Crust, Siberian Branch of RAS

128 Lermontov street, Irkutsk 664033, Russia

Tel.: 8(3952)511665; \ e-mail: skl@crust.irk.ru

\author{
Добрынина Анна Александровна, канд. физ.-мат. наук, н.с. \\ Институт земной коры СО РАН \\ 664033, Иркутск, ул. Лермонтова, 128, Россия \\ e-mail: dobrynina@crust.irk.ru
}

Dobrynina, Anna A., Candidate of Physics and Mathematics, Researcher

Institute of the Earth's Crust, Siberian Branch of RAS

128 Lermontov street, Irkutsk 664033, Russia

e-mail: dobrynina@crust.irk.ru 
E.V. Sklyarov et al.: XXVI All-Russia youth conference "Lithosphere structure and Geodynamics"...

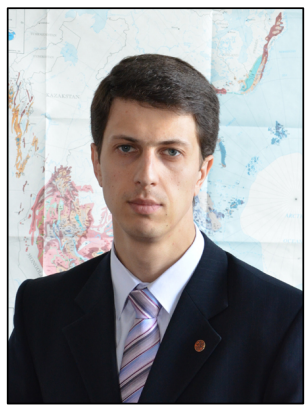

Кононов Александр Матвеевич, канд. геол.-мин. наук, заместитель директора по науке Институт земной коры СО РАН

664033, Иркутск, ул. Лермонтова, 128, Россия

e-mail: kononov@crust.irk.ru

Kononov, Alexander M., Candidate of Geology and Mineralogy, Deputy Director

Institute of the Earth's Crust, Siberian Branch of RAS

128 Lermontov street, Irkutsk 664033, Russia

e-mail: kononov@crust.irk.ru 